Review

\title{
Review of State of the Art Recycling Methods in the Context of Dye Sensitized Solar Cells
}

\author{
Fabian Schoden ${ }^{1, *} \mathbb{E}$, Marius Dotter ${ }^{1,2} \mathbb{D}$, Dörthe Knefelkamp ${ }^{1}$, Tomasz Blachowicz ${ }^{3} \mathbb{C}$ \\ and Eva Schwenzfeier Hellkamp ${ }^{1}$ \\ 1 Institute for Technical Energy Systems (ITES), Bielefeld University of Applied Sciences, \\ 33619 Bielefeld, Germany; marius.dotter@fh-bielefeld.de (M.D.); doerthe.knefelkamp@fh-bielefeld.de (D.K.); \\ eva.schwenzfeier-hellkamp@fh-bielefeld.de (E.S.H.) \\ 2 Department of Physics, Bielefeld University, 33615 Bielefeld, Germany \\ 3 Institute of Physics-Center for Science and Education, Silesian University of Technology, \\ 44-100 Gliwice, Poland; tomasz.blachowicz@polsl.pl \\ * Correspondence: fabian.schoden@fh-bielefeld.de; Tel.: +49-521106-7386
}

Citation: Schoden, F.; Dotter, M.;

Knefelkamp, D.; Blachowicz, T.;

Schwenzfeier Hellkamp, E. Review of State of the Art Recycling Methods in the Context of Dye Sensitized Solar Cells. Energies 2021, 14, 3741.

https://doi.org/10.3390/en14133741

Academic Editor: Claudia Barolo

Received: 24 May 2021

Accepted: 18 June 2021

Published: 22 June 2021

Publisher's Note: MDPI stays neutral with regard to jurisdictional claims in published maps and institutional affiliations.

\begin{abstract}
In times of climate change and dwindling fossil resources, the need for sustainable renewable energy technologies gains importance, increasingly fast. However, the state of the art technologies are energy intensive in their production, like monocrystalline photovoltaic, or even consist of not recyclable composite material, in the case of wind turbine blades. Despite a lack in efficiency and stability, dye sensitized solar cells (DSSC) have a high potential to supplement the state of the art green energy technology in future. With low production costs and no necessity for toxic compounds DSSCs are a potential product, which could circulate in the loops of a circular economy. Therefore, with this paper, we provide the status of research on DSSC recycling and an outlook on how recycling streams could be realized in the future for glass-based DSSCs without toxic components. The overview includes work on using recycled material to build DSSCs and extending the life of a DSSC, e.g., through rehydration. We also illustrate the state of sustainability research for DSSCs using the VOSviewer tool. To date, the term sustainability appears in 35 of 24,441 publications on DSSCs. In view of the global challenges, sustainability should be researched more seriously because it is as important as the efficiency and stability of DSSCs.
\end{abstract}

Keywords: dye sensitized solar cell; recycling; non-toxic materials; circular economy; healthy energy systems; sustainability

\section{Introduction}

In order to reduce the temperature rise of the global climate, energy from renewable sources plays an important role [1]. In this context, interest in dye-sensitized solar cells (DSSCs) is increasing [2]. This technology could be integrated into windows, facades, cars, Internet-of-things devices or used as smart building blocks [3,4]. DSSCs are functional and efficient even in diffuse light, therefore they can generate electricity in the morning, evening and even indoors [5]. Even as silicon prices fall and silicon-based photovoltaics become cheaper, DSSCs have great potential as they can be used in additional applications such as indoor and diffuse light [6]. With a variety of fields of application, huge quantities of DSSCs could be produced in the future. Similar to the price decline in the photovoltaic market, the prices for industrially manufactured DSSCs will also fall [7]. Thinking ahead, this material will eventually end up in recycling processes. Applying the concept of the circular economy, there is now an opportunity to design DSSCs in such a way that they can be easily recycled at the end of their useful life. Since DSSCs have not yet reached the mass market, the potential for holistic design concepts is great. Around $70 \%$ of the environmental impact of a product is already predetermined in the design phase [8]. 
In a circular economy, it is essential to move away from the concept of waste [9]. Thus, every material and product can be used for something new at the end of its life. The products flow in cycles-a biological and a technical cycle. Products made of technical materials, such as glass and metal, flow in the technical cycle. The focus is on extending the life and intensifying the use phase and value of a product. Therefore, before the actual recycling of a product and the use of the basic material, there are processes such as sharing, repairing, refurbishing and remanufacturing. At the end of the product's life, it must still be recycled [10].

DSSCs with the highest efficiency are using materials like ruthenium, cobalt, silver and platinum [3], which are toxic or scarce [11]. Thus, these DSSCs pose high risk to people working with the cells, the environment in which they will be used and at the end, the toxic waste must be disposed of.

Therefore, we only use materials for our DSSCs that are non-toxic and abundant [12-15]. These cells could be reused and recycled and pose no danger to humans or the environment. However, these cells cannot compete with high efficiency cells, such as the rutheniumpolypyridyl cells also known as N3 or N719, with an efficiency above 10\% [16]. Non-toxic cells typically achieve efficiencies well below 1\% [17,18]. Ganta et al. achieved a power conversion efficiency (PCE) of $0.740 \%$ with plant dyes from the cladode (nopal) of the thornless prickly pear cactus (Opuntia ficus-indica) [19]. If the electrolyte of such cells is refilled, the cells can be used for at least four months. [20]. To further improve the longevity, gel electrolytes can be used, then the cells last at least 140 days without refilling [21]. Stateof-the-art DSSCs achieve efficiencies above $14 \%$ in laboratory experiments [22]. Freitag et al. used $\mathrm{Cu}(\mathrm{II} / \mathrm{I})(\mathrm{tmby})_{2}$ redox mediator and XY1 and D35 sensitizers with 1000 lux illumination to reach a PCE of $28.9 \%$ [23]. Cells with the highest PCE do not necessarily deliver the longest lifetime or stability. Chen et al. measured an efficiency of $5.46 \%$ with their solid-state DSSC. They used PVB-SPE (polyvinylbutyral-quasi-solid polymeric electrolyte) as the electrolyte and achieved a cell lifetime of $3000 \mathrm{~h}$ [24]. For commercial applications, a lifetime of five years is required for portable electronic devices or textiles. For building applications, a lifetime of more than 25 years is required to compete with silicon-based photovoltaics $[25,26]$.

To develop a safe, recyclable and environmentally friendly technology, it is necessary to use only non-toxic materials. The use of toxic materials increases efficiency and stability but hinders recycling. A similar process can be seen today with CdTe cells. CdTe panels have some advantages, such as lower energy consumption in the production process than $\mathrm{Si}$ modules, and therefore lower $\mathrm{CO}_{2}$ emissions. However, cadmium is a very toxic material and if the modules are not recycled or are recycled incorrectly, they pose a threat to human, aquatic and terrestrial life [27].

With a new product that is not yet in mass production, namely DSSCs, we have the opportunity to avoid waste, inspired by the circular economy. In the circular economy, it is important not to use harmful substances and to enable technical products that can be repaired, remanufactured or recycled. In this paper, we will take a closer look at the state of the art of DSSC recycling and show what research is underway to improve the recyclability of DSSCs. To close material loops, as for any other effective sustainable action in life, it is important to start with the end in mind. In this case, it is clear that more DSSCs will be in use in the future and will need to be recycled at the end of their useful life. Therefore, DSSCs must be designed to be non-toxic and to be able to be broken down into materials that are as pure as possible.

\section{Relevance of Sustainability in DSSC Research}

To date, sustainability has played a subordinate role in DSSC research. In order to visualize this statement, data from the Web of Science were evaluated using the VOSviewer tool. VOSviewer is a tool developed by Nees Jan van Eck and Ludo Waltman at Leiden University's Centre for Science and Technology Studies (CWTS). With the software tool bibliometric networks can be constructed and visualized. With the text mining func- 
tion co-occurrence networks of important terms can be visualized [28]. The search result for 'dye sensitized solar cell' from the Web of Science returned 24,441 publications (15 March 2021). The titles and abstracts were exported and then evaluated using the VOSviewer tool. The results are shown in Figure 1.

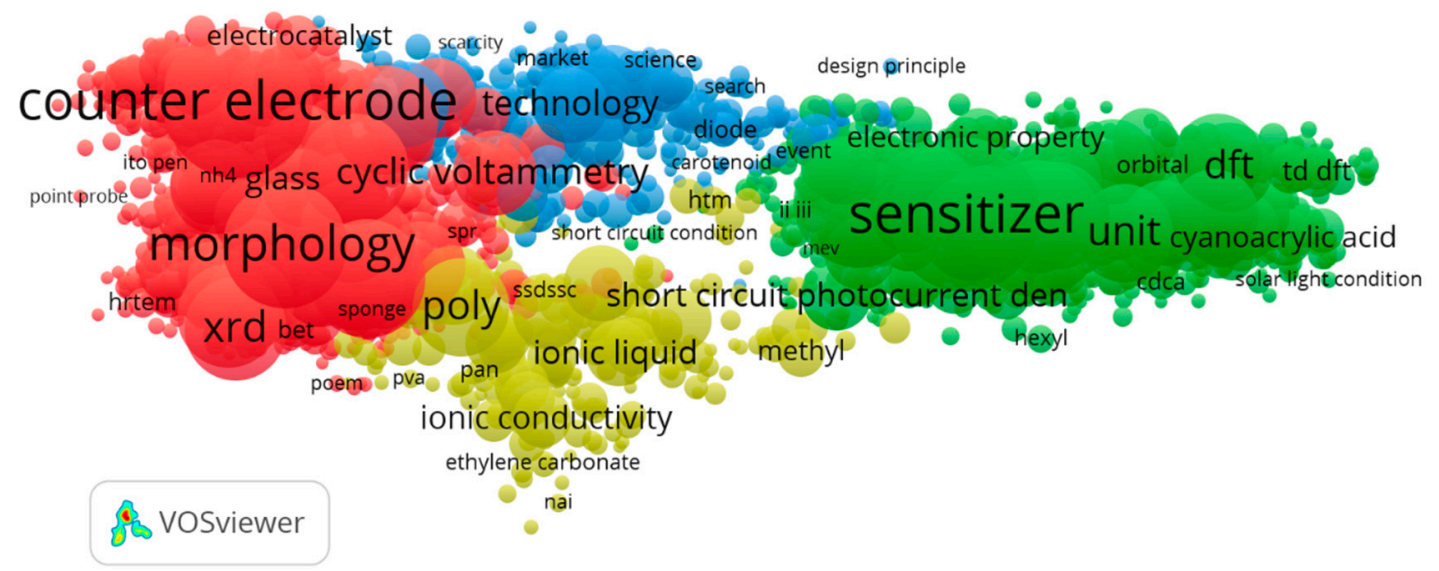

Figure 1. Terms from titles and abstracts of DSSC papers visualized with the VOSviewer tool.

Each point represents a term from the titles and abstracts of the publications in our dataset. The terms of interest are located based on their co-occurrence in the title and abstract. The higher the number of co-occurrences of two terms, the closer they are located on the map. In green, we see publications that focus on the sensitizer, red are publications about the counter electrode and morphology, the blue area focuses on the technology part, sustainability is also located here. In yellow, we see publications that focus on the electrolyte. The overall frequencies of some important terms are: "counter electrode (appears 2769 times)", "sensitizer (appears 2810 times)" or "morphology (appears 1899 times)". Sustainability, on the other hand, occurs only 35 times and is thus, not visible in Figure 1.

Figure 2 shows the same graph but different colors for the average publication date. Blue for older publications and yellow for recent publications.

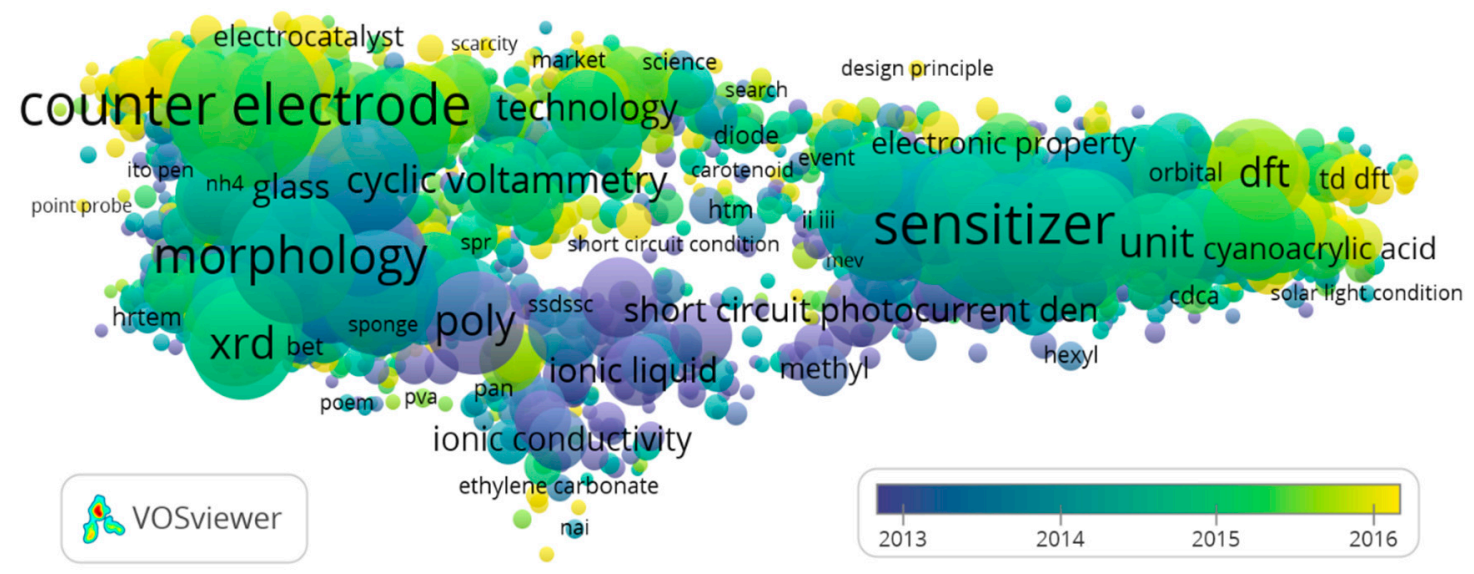

Figure 2. Terms from titles and abstracts of DSSC papers colored by novelty.

For example, terms such as "scarcity (appears 26 times)" and "energy demand (appears 65 times)" are associated with sustainability and appear in yellow with an average publication date of 2017.09 (February 2017) for "energy demand" and "scarcity" 2016.31 (April 2016), indicating that this research field is relatively new and under-researched. The average publication date shows the average date of all publications containing the 
term, in this case "energy demand". The average publication date of 65 papers containing "energy demand" is 2017.09. Since a year with a decimal number is not very intuitive, we have also indicated the average date as (month year).Table 1 shows the most important terms ranked by the total appearance.

Table 1. Important Terms, total appearances and average publication date.

\begin{tabular}{ccc}
\hline Term & Appearances & Average Publication Date \\
\hline sensitizer & 2810 & 2014.43 (June 2014) \\
counter electrode & 2769 & 2015.10 (February 2015) \\
molecule & 2086 & 2014.16 (February 2014) \\
group & 2263 & 2014.58 (July 2014) \\
morphology & 1899 & 2014.44 (June 2014) \\
organic dye & 1396 & 2014.61 (August 2014) \\
series & 1357 & 2014.43 (June 2014) \\
substrate & 1474 & 2013.57 (July 2013) \\
xrd (x ray diffraction) & 1316 & 2014.84 (November 2014) \\
\hline
\end{tabular}

In Figure 3, the graph is zoomed in to make the term sustainability visible.

future prospect

future research

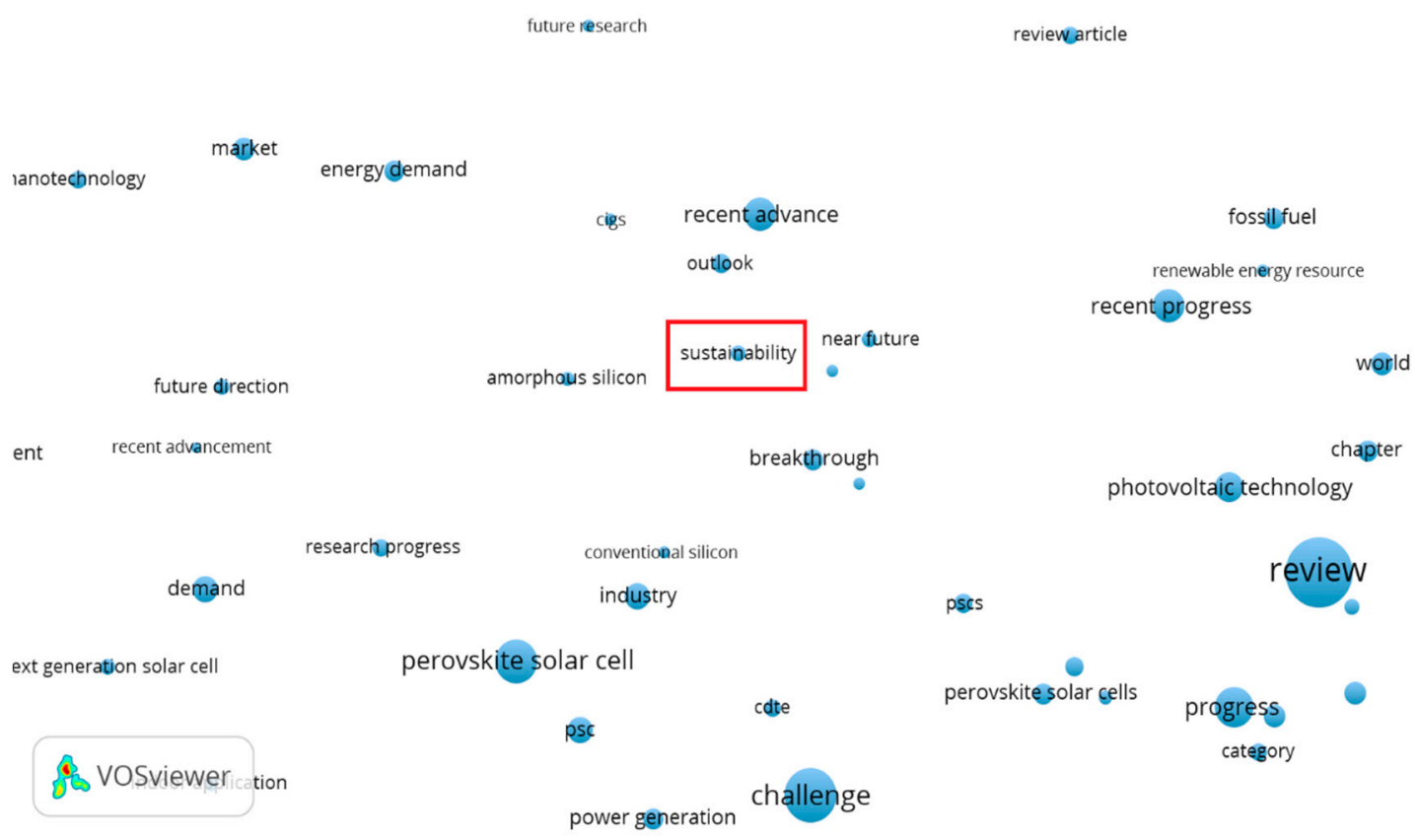

Figure 3. Zoomed illustration of the terms from titles and abstracts of DSSC papers to make "sustainability" visible.

The term sustainability appears 35 times. This underlines the statement that sustainability research does not yet play a major role in the field of DSSCs. However, the average publication date of 2017.03 (January 2017) underscores the growing relevance of the topic in this research field. Nevertheless, with the outlook on the great potential of DSSCs for the mass market, emphasized in the introduction, the urgency to intensify research on sustainable DSSCs becomes visible.

Following steps were used to produce these graphs (VOSviewer version 1.6.16, Leiden University's Centre for Science and Technology Studies (CWTS), Netherlands):

1. Download abstracts and titles from the web of science with the search results of "dye sensitized solar cell" (24,441 results).

2. Create map based on text data (term map). 
3. Read data from bibliographic database files.

4. Select web of science data.

5. Title and abstract.

6. Binary counting (only the presence or absence of a word matters not the number of the occurrences).

7. Minimum number of occurrences (10).

\section{Fundamental Structure of a DSSC}

Figure 4 shows the schematic structure of a DSSC, which is briefly explained below. The basis for the DSSC, which is classically used in laboratories to investigate various properties of DSSCs, is two coated glass plates (0). A thin transparent conductive oxide (TCO) layer is deposited on the glass plates, referred to as the front and counter electrodes $(0)[14,29]$. The main task of these conductive semiconductor layers, which are transparent to visible light, is to transport the charge carriers generated in the cell by the internal photoelectric effect [14,29]. Light absorption and the resulting induced charge separation takes place in the dye molecules (2) $[14,30]$. These are often toxic ruthenium dyes. Anthocyanins are often used as a less effective, but cheaper and non-toxic alternative $[14,29,30]$. They are bonded to a semiconductor layer, e.g., titanium dioxide, which is located on the front electrode (1) $[14,29,31]$. For the regeneration of the dye, the redox reaction of an electrolyte, often based on Lugol's solution, is used (3) $[14,29,30]$. Research is being conducted into liquid, gel-like and solid forms of the electrolyte. Solid and quasi-solid solutions have the advantage of being more durable than DSSCs with liquid electrolyte $[14,29,30]$. The catalyst layer is required for an effective regeneration process of the dye (4) [14,32]. Platinum enables DSSCs with the highest efficiency. Graphite is widely used as a lower cost and less toxic option. [14,32]. The catalyst layer is applied to the counter electrode. Here the electrons, taken from the DSSC, can re-enter and the electrical circuit is closed [14,32].

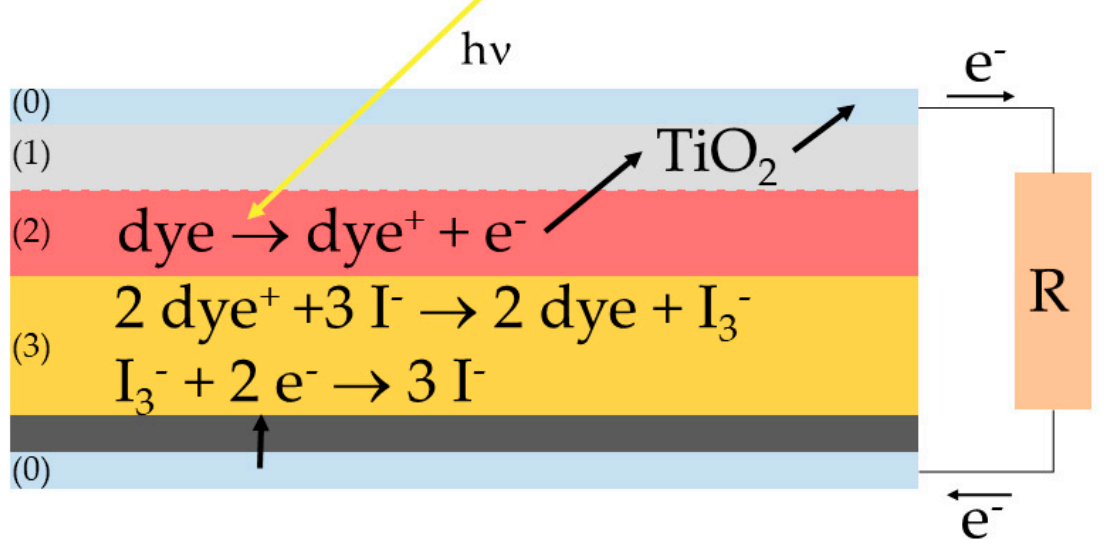

Figure 4. Schematic structure of a dye-sensitized solar cell.

\section{Using Recycled Material to Build DSSCs}

One approach is to use recycled material to build DSSCs. The use of recycled material can reduce energy requirements and costs compared to the procurement of raw materials. For aluminum, energy savings of up to $95 \%$ can be achieved [33].

Daut et al. used recycled carbon from batteries for the counter electrode of DSSCs. They used the doctor-blade method to deposit thin homogeneous layers and achieved $0.33 \mathrm{~V}$ at an average solar irradiance of $693.69 \mathrm{~W} / \mathrm{m}^{2}$ at $44.4{ }^{\circ} \mathrm{C}$ [34]. Nair et al. compared two carbon sources for the counter electrode, pencil lead and recycled carbon from batteries. They concluded that the DSSC counter electrode with carbon from recycled batteries has a higher efficiency than cells with pencil lead [35]. Both options could improve the residual material stream for batteries or nearly spent pencils. However, carbon powder is not expensive and the recycling process of old batteries or pencils could therefore increase 
the price of future DSSCs. Using pencil lead as a carbon source is common, but does not result in the highest cell efficiencies [36]. Due to its formidable mechanical, optoelectronic, chemical and thermal properties, graphene-based DSSCs could become a sustainable solution [37].

Chen et al. took thin film transistor liquid crystal displays (TFT-LCD) and used the color filter glass to fabricate DSSC. These glasses are coated with indium tin oxide (ITO). Nevertheless, they had to improve the conductivity with copper nanowires. They point out that the conductive glass for a DSSC accounts for 30\% of the total cost. With recycled material, costs could be reduced [38]. Ayaz et al. used old telephone screens as counter electrodes for DSSC production. They took the conductive screen, cleaned it and applied carbon to the glass with a candle flame [39].

Another approach by Zhu et al. could be to recover the valuable conductive glass and $\mathrm{TiO}_{2}$ layer from old cells. In their case, they recycled the $\mathrm{FTO} \mathrm{TiO}_{2}$ glass from perovskite cells. They removed the top layers of the perovskite cell and applied fresh $\mathrm{CsPbIBr}_{2}$ and carbon layers [40]. $\mathrm{TiO}_{2}$ is commonly used in DSSCs because it is the best trade of between sustainability and efficiency [41].

Table 2 visualizes the main information collected for the use of recycled material to build DSSCs.

Table 2. Overview of the recycled material used and efficiencies achieved.

\begin{tabular}{ccc}
\hline Material & Application & Efficiency \\
\hline Carbon from batteries & Counter electrode & Not stated [34] \\
Carbon from batteries & Counter electrode & $8.2 \%[35]$ \\
Carbon from pencils & Counter electrode & $7.23 \%[35]$ \\
Telephone screens & Conductive glass & $0.0244 \%[39]$ \\
TFT-LCD & Conductive glass & $3.94 \%[38]$ \\
Perovskite cells & Conductive glass with $\mathrm{TiO}_{2}$ & $9.12 \%[40]$ \\
\hline
\end{tabular}

All publications available at this time on the use of recycled material for the construction of DSSCs are listed above. These approaches could lead to more resource efficiency, energy savings in DSSC production and circular use of materials. However, since the recycled material for the electrodes is not designed for these cells, unless old cells are used, the use case needs to be thoroughly investigated. A negative example of recycling and a bad use case is paper recycling, because food packaging was made from recycled paper, mineral oil components were in the food packaging and could migrate into the food [42]. This does not necessarily apply to the above examples, but it is important to not only investigate how the residual materials could be reused, but also to think about the next step-what happens to the DSSCs during the use phase and after their service life. Can the glass still be recycled or will chemical residues remain and, for example, reduce the glass quality or even hinder the recycling process? The economic viability of the individual recyclates must be investigated.

\section{Increasing the Longevity of DSSC}

One step before actual recycling is to extend the lifetime of the DSSC. One reason for the short lifetime is the drying out of the electrolyte [43]. To prevent this, the cells could be encapsulated and solid-state or quasi-solid (gel) electrolytes could be used [44]. Instead of gel electrolytes derived from petroleum, biopolymer-based electrolytes should be used. That could be for instance, chitosan, carrageenan, cellulose, starch or agarose based solutions as well as xanthan gum [45-48]. Encapsulating DSSCs adds another type of material to the system and can make recycling more difficult. Common Si modules are encapsulated with polymer ethylene vinyl acetate (EVA), which causes problems for the recycling process. To date, the EVA can only be removed by pyrolysis. This process is very energy intensive and destroys the EVA thermally [49]. 
Juhász Junger et al. investigated how refilling cells with electrolyte can extend cell lifetime [20]. Rehydration is especially essential for DSSC technology integrated into textiles. In devices such as tents, morning dew could potentially rehydrate the cells, and in air with high humidity, such as in some greenhouses, moisture could potentially rehydrate the cells [50].

Chen et al. used $\mathrm{NaOH}$ as a desorbent to purify the front electrode from residual dye, in their case $\mathrm{RuL}_{2}(\mathrm{NCS})_{2}-2 \mathrm{TBA}$, also known as N719. After the desorption process, they applied fresh dye to the front electrode to show that old cells could potentially be reused or upgraded with more efficient dyes [51]. In previous experiments, it was even shown that the dyeing process could be accelerated and the dye density improved with each desorption and adsorption process [52].

However, the Ruthenium A-based dye N719 is toxic and the rinsing liquid ( $\mathrm{NaOH}$ mixed with N719) must be handled with care. Environmentally friendly natural dyes based on carotenoids, chlorophylls, anthocyanins derived from plants could be alternatives [53,54].

\section{Outlook and Development: Scaling up and Estimation of Recycling Material}

The DSSC market is growing. The global DSSC market size 2019 was USD 90.5 million. The compound annual growth rate from 2020 to 2027 is estimated with 12.4\% [2]. Since the DSSC production is insensitive to impurities, it is easier to upscale the process from lab scale to industrial scale [31]. S. Mozaffari et al. came to the result that due to the lack in efficiency and long-term stability DSSCs are no serious competitor to common silicon-based photovoltaics [55]. However, many other studies as well as the prediction for the market growth, estimate that DSSC technology has great potential and probably will enter the mass market soon $[3,26,43,56]$.

Reviews show that a large variety of material is used for making DSSCs [57-60]. Other researchers like N. Mariotti et al. also point out that the research focusses on the efficiency and stability of DSSCs while neglecting sustainability [3]. They made a sustainability review for each component of the DSSC and essential design guides are to use non-toxic, readily available and low cost, waste derived easy recyclable materials. While, relating to different studies the most important environmental problems concerning DSSCs are $[3,26,31,55,56]$ :

- Use of critical raw materials or precious metals: this problem occurs when toxic and rare materials are used to increase cell efficiency. However, it is possible to use non-toxic, abundant materials. Therefore, this main problem can be addressed by designing DSSCs without toxic materials.

- Performance degradation due to electrolyte stability: the use of solid-state or quasisolid-state electrolytes based on biopolymers could address this problem.

- High energy demand for producing transparent conductive oxide (TCO)/glass: This statement comes from life cycle analysis (LCA) with a cradle-to-gate perspective. Cradle-to-gate determines the scope of the life cycle assessment. Here, cradle stands for the extraction of the raw material. Further steps are the transport and processing of the product. Gate stands for the point at which the product leaves the company. In this LCA, all environmental impacts within the scope, from raw material extraction to product completion, were assessed. The impacts thereafter-the transport, the use phase and the disposal or a possible recycling process-were not considered. If it were possible to use recycled glass for DSSCs or even allow recycling of DSSCs, the energy requirement would decrease. A new LCA needs to be calculated to re-evaluate the environmental impact of glass-based DSSCs with a cradle-to-cradle approach.

- Sustainability aspects related to unsafe waste management: if non-toxic material is used, it is easier to define specific waste management as well as to close material loops and recycle DSSCs.

The main components of DSSCs are presented below to highlight important environmental aspects. Table 3 shows examples of relevant dyes for the construction of DSSCs, their advantages and disadvantages, and the reported efficiencies. 
Table 3. Examples of relevant dyes in DSSC research, their advantages and disadvantages, and reported efficiencies.

\begin{tabular}{cccc}
\hline Dye & Advantage & Disadvantage & Efficiency \\
\hline D- -A-A/Adeka 1 & High stability and PCE & Cobalt-based electrolyte & $12.5 \%[61]$ \\
Zn-Porphyrin/YD2-o-C8 & High stability and PCE & Cobalt-based electrolyte & $11.9 \%[62]$ \\
Chlorophylls/Chlorophyll cl & Natural dye & Low stability and PCE & $3.4 \%[63]$ \\
Flavonoids/Anthocyanin & Natural dye & Low stability and PCE & $1.1 \%[64]$ \\
\hline
\end{tabular}

Natural and metal-free dyes such as anthocyanin or chlorophyll are biodegradable and non-toxic. In a possible recycling process, they would not cause any health problems. While ruthenium- or cobalt-based dyes could hinder the reuse of material from DSSC due to their environmental and health problems [3].

The redox couples are typically iodine- or cobalt-based. However, iodine-based redox couples suffer from degradation and cobalt is a critical raw material [37]. Alternatives could be copper-based redox couples such as [ $\mathrm{Cu}(2 \text {-mesityl-4,7-dimethyl-1,10-phenanthroline) })^{2+/+}[65]$. Copper is less toxic [37], more environmental friendly [65] and two times more abundant compared to cobalt [37]. Table 4 presents examples of relevant redox couples in DSSC research, their advantages and disadvantages, and reported efficiencies.

Table 4. Examples of relevant redox couples in DSSC research, their advantages and disadvantages, and reported efficiencies.

\begin{tabular}{cccc}
\hline Redox Couple & Advantage & Disadvantage & Efficiency \\
\hline Pseudo-halogens & Suitable for quasi-solid electrolytes & Toxicity, use of selenium & $2.6 \%[66]$ \\
Iron-based complexes & Water as solvent & Low stability & $2.9 \%[67]$ \\
Copper-based complexes & Low toxicity dye & Organic solvent-based electrolyte & $4.4 \%[65]$ \\
\hline
\end{tabular}

The organic solvents required for the copper-based redox couples are problematic because they are volatile, flammable and unstable [68].

The use of platinum for the cathode is associated with major environmental impacts due to the energy and chemicals consumed during extraction and processing [56]. Therefore, a recycling process or even the replacement of platinum would improve the environmental issue [69,70]. Alternatives for the cathode could be poly(3,4-ethylenedioxythiophene) (PEDOT) or carbon materials [71]. Di et al. used organic biomass and got carbon based material for the cathode by applying pyrolysis. They reached an PCE of $6.14 \%$ [72]. Remi et al. reached a PCE of $4.5 \%$ with a PEDOT cathode [73].

De Wild-Scholten et al. conclude that recycling TCO-glass could potentially reduce the energy required for production and thus dramatically improve the environmental impact of DSSCs [74]. However, no practical experience has yet been documented for DSSC recycling [74]. Parisi et al. considered $\mathrm{TiO}_{2}$ and explained that $\mathrm{TiO}_{2}$ is available in large quantities and the recycling process for such semiconductors will be complex [56]. For this reason, it will be difficult to implement a feasible process to recover $\mathrm{TiO}_{2}$ from old DSSCs. Parisi et al. also investigated the sensitizer and pointed out that especially for metal-based dyes a recycling process is important, both from an environmental and economic point of view [56]. If platinum is used as part of the counter electrode, it is a high priority to recover it as well. They conclude that the recycling process of photovoltaics is economically less favorable compared to landfilling the old modules [56,75]. Since there are no practical data for large-scale DSSC recycling, data for glass and metal recycling from silicon-based photovoltaics were used for the LCAs [26].

Peng et al. compared the greenhouse gas emissions of photovoltaic technologies and found that DSSCs are still no better than conventional solar cells [76]. However, they conclude that in the future, with higher efficiencies and lower material consumption, DSSCs could outperform conventional solar cells in terms of lower greenhouse gas emissions [76].

Finally, material recovery is becoming increasingly important and, in the case of silicone-based photovoltaics, is mandated by European legislation such as the WEEE (Waste Electrical and Electronic Equipment) declaration [77]. Furthermore, the recovery 
of critical raw materials through recycling is essential in order to become independent of finite fossil sources. This is particularly true for resource-poor countries such as Germany or Japan.

Furthermore, Mariotti et al. focus on the challenge of climate change and mention that the energy sector is responsible for most of the $\mathrm{CO}_{2}$ emissions. Which seems true at first glance, but the real problem is probably not the energy demand, but the huge throughput by our linear economy that consumes or demands all this energy. Therefore, instead of improving energy production, we should become more effective with our material use and thus reduce energy demand $[78,79]$. In addition, due to the pressure to perform in DSSC efficiency research, the so-called reproducibility crisis is an acute problem. Researchers try to produce DSSCs with highest efficiencies and the obtained results are not reproducible $[32,80-82]$. To go further than just maximizing the sustainability of the individual components, the complete system must ultimately be recyclable.

\section{Conclusions}

The DSSC market is growing and a wide range of applications will be possible. In addition, DSSCs are leading photovoltaic technology when it comes to environmental aspects. Nevertheless, the visibility of sustainability research in the research field of DSSCs is very low, as this paper shows. Obstacles such as low efficiency and long-term stability need to be improved with sustainable solutions.

Parts of DSSCs can be built from secondary or recycled materials. However, some recycled materials cannot compete in price with the raw material, for example, carbon from recycled batteries. In addition, the use of recycled material may introduce harmful or undesirable substances into the DSSC, making the use and recycling phases more hazardous, difficult, or unpredictable. Therefore, quality control must be established if recycled material is to become a basic building block for DSSCs. The lifetime of DSSCs can be extended by rehydration or desorption and adsorption of the dye. Solid or quasi-solid electrolytes based on biopolymers could become sustainable solutions for the long-term stability of DSSCs.

Considering the global climate crisis and resource scarcity, sustainability should be given the same importance or weight as efficiency and stability in DSSC research.

Author Contributions: Conceptualization, investigation, writing-original draft preparation, funding acquisition, methodology, visualization and data curation F.S.; validation, supervision, project administration E.S.H. and T.B.; formal analysis, writing-review and editing D.K., M.D. and F.S. All authors have read and agreed to the published version of the manuscript.

Funding: The project was partly funded by the European Regional Development Fund (ERDF) as well as from the State of NRW in scope of the project CirQuality OWL and the project NanoDSSC (progress.nrw). We acknowledge support by the Open Access Publication Fund of the University of Applied Sciences Bielefeld.

Institutional Review Board Statement: Not applicable.

Informed Consent Statement: Not applicable.

Data Availability Statement: In the data, which was analyzed and sourced in the Web of Science by searching for "dye sensitized solar cells" the data was downloaded and processed with the VOSviewer tool, as described in this paper.

Acknowledgments: We thank Jan Lukas Storck for constructive criticism of the manuscript.

Conflicts of Interest: The authors declare no conflict of interest. The funders had no role in the design of the study; in the collection, analyses, or interpretation of data; in the writing of the manuscript, or in the decision to publish the results. 


\section{References}

1. Baruch-Mordo, S.; Kiesecker, J.; Kennedy, C.M.; Oakleaf, J.R.; Opperman, J.J. Erratum: From Paris to Practice: Sustainable Implementation of Renewable Energy Goals. Environ. Res. Lett. 2019, 14, 024013. [CrossRef]

2. Coverage, R. Dye Sensitized Solar Cell Market Growth Report, 2020-2027. 2021. Available online: https://www. Grandviewresearch.Com/Industry-Analysis/Dye-Sensitized-S (accessed on 19 June 2021).

3. Mariotti, N.; Bonomo, M.; Fagiolari, L.; Barbero, N.; Gerbaldi, C.; Bella, F.; Barolo, C. Recent advances in eco-friendly and cost-effective materials towards sustainable dye-sensitized solar cells. Green Chem. 2020, 22, 7168-7218. [CrossRef]

4. Yuan, H.; Wang, W.; Xu, D.; Xu, Q.; Xie, J.; Chen, X.; Zhang, T.; Xiong, C.; He, Y.; Zhang, Y.; et al. Outdoor testing and ageing of dye-sensitized solar cells for building integrated photovoltaics. Sol. Energy 2018, 165, 233-239. [CrossRef]

5. Kawakita, J. Trends of Research and Development of Dye-Sensitized Solar Cells. Sci. Technol. Trends 2010, 35, 70-82.

6. Trancik, J.E.; Cross-Call, D. Energy Technologies Evaluated against Climate Targets Using a Cost and Carbon Trade-off Curve. Environ. Sci. Technol. 2013, 47, 6673-6680. [CrossRef] [PubMed]

7. van Sark, W.G.J.H.M.; Schoen, T. Photovoltaic System and Components Price Development in The Netherlands. In Proceedings of the 33rd European Photovoltaic Solar Energy Conference and Exhibition, Amsterdam, The Netherlands, 25-29 September 2017; pp. 2866-2869.

8. Rebitzer, G. Integrating Life Cycle Costing and Life Cycle Assessment for Managing Costs and Environmental Impacts in Supply Chains. Cost Manag. Supply Chain. 2002, 127-146. [CrossRef]

9. Ellen MacArthur Foundation and McKinsey. Growth within: A Circular Economy Vision for a Competitive Europe; Ellen MacArthur Foundation: Cowes, UK, 2015; p. 100.

10. The Ellen MacArthur Foundation. Towards the Circular Economy. An Economic and Business Rationale for an Accelerated Transition; Ellen MacArthur Foundation: Cowes, UK, 2013; p. 96.

11. Ehrmann, A.; Błachowicz, T. Solarstrom aus Früchtetee. Phys. Unserer Zeit 2020, 51, 196-200. [CrossRef]

12. Kohn, S.; Großerhode, C.; Storck, J.L.; Grötsch, G.; Cornelißen, C.; Streitenberger, A.; Grassmann, C.; Schwarz-Pfeiffer, A.; Ehrmann, A. Commercially available teas as possible dyes for dye-sensitized solar cells. Optik 2019, 185, 178-182. [CrossRef]

13. Gossen, K.; Storck, J.; Ehrmann, A. Influence of solvents on Aloe vera gel performance in dye-sensitized solar cells. Optik 2019, 180, 615-618. [CrossRef]

14. Storck, J.; Dotter, M.; Adabra, S.; Surjawidjaja, M.; Brockhagen, B.; Grothe, T. Long-Term Stability Improvement of NonToxic Dye-Sensitized Solar Cells via Poly (ethylene oxide) Gel Electrolytes for Future Textile-Based Solar Cells. Polymers 2020, 12, 3035. [CrossRef]

15. Junger, I.J.; Großerhode, C.; Storck, J.L.; Kohn, S.; Grethe, T.; Grassmann, C.; Schwarz-Pfeiffer, A.; Grimmelsmann, N.; Meissner, H.; Blachowicz, T.; et al. Influence of graphite-coating methods on the DSSC performance. Optik 2018, 174, 40-45. [CrossRef]

16. Sun, P.-P.; Li, Q.-S.; Yang, L.-N.; Sun, Z.-Z.; Li, Z.-S. Theoretical investigation on structural and electronic properties of organic dye $\mathrm{C} 258$ on $\mathrm{TiO}_{2}$ (101) surface in dye-sensitized solar cells. Phys. Chem. Chem. Phys. 2014, 16, 21827-21837. [CrossRef] [PubMed]

17. Ehrmann, A.; Blachowicz, T. Comment on Dye-sensitized solar cells using Aloe Vera and Cladode of Cactus extracts as natural sensitizers. Chem. Phys. Lett. 2019, 714, 227-229. [CrossRef]

18. Ehrmann, A.; Blachowicz, T. Recent coating materials for textile-based solar cells. AIMS Mater. Sci. 2019, 6, 234-251. [CrossRef]

19. Ganta, D.; Jara, J.; Villanueva, R. Dye-sensitized solar cells using Aloe Vera and Cladode of Cactus extracts as natural sensitizers. Chem. Phys. Lett. 2017, 679, 97-101. [CrossRef]

20. Junger, I.J.; Tellioglu, A.; Ehrmann, A. Refilling DSSCs as a method to ensure longevity. Optik 2018, 160, 255-258. [CrossRef]

21. Gossen, K.; Ehrmann, A. Glycerin-based electrolyte for reduced drying of dye-sensitized solar cells. Optik 2020, 207, 163772. [CrossRef]

22. Gong, J.; Sumathy, K.; Qiao, Q.; Zhou, Z. Review on dye-sensitized solar cells (DSSCs): Advanced techniques and research trends. Renew. Sustain. Energy Rev. 2017, 68, 234-246. [CrossRef]

23. Freitag, M.; Teuscher, J.; Saygili, Y.; Zhang, X.; Giordano, F.; Liska, P.; Hua, J.; Zakeeruddin, S.M.; Moser, J.-E.; Grätzel, M.; et al. Dye-sensitized solar cells for efficient power generation under ambient lighting. Nat. Photonics 2017, 11, 372-378. [CrossRef]

24. Chen, K.F.; Liu, C.H.; Huang, H.K.; Tsai, C.H.; Chen, F.R. Polyvinyl Butyral-Based Thin Film Polymeric Electrolyte for DyeSensitized Solar Cell with Long-Term Stability. Int. J. Electrochem. Sci. 2013, 8, 3524-3539.

25. Baxter, J.B. Commercialization of dye sensitized solar cells: Present status and future research needs to improve efficiency, stability, and manufacturing. J. Vac. Sci. Technol. A 2012, 30, 020801. [CrossRef]

26. Parisi, M.; Maranghi, S.; Vesce, L.; Sinicropi, A.; Di Carlo, A.; Basosi, R. Prospective life cycle assessment of third-generation photovoltaics at the pre-industrial scale: A long-term scenario approach. Renew. Sustain. Energy Rev. 2020, 121, 109703. [CrossRef]

27. Vellini, M.; Gambini, M.; Prattella, V. Environmental impacts of PV technology throughout the life cycle: Importance of the end-of-life management for Si-panels and CdTe-panels. Energy 2017, 138, 1099-1111. [CrossRef]

28. Van Eck, N.J.; Waltman, L. Software survey: VOSviewer, a computer program for bibliometric mapping. Scientometrics 2010, 84, 523-538. [CrossRef]

29. Kang, M.-S.; Kim, J.H.; Won, J.; Kang, Y.S. Oligomer Approaches for Solid-State Dye-Sensitized Solar Cells Employing Polymer Electrolytes. J. Phys. Chem. C 2007, 111, 5222-5228. [CrossRef]

30. Kim, J.H.; Kang, M.-S.; Kim, Y.J.; Won, J.; Park, N.-G.; Kang, Y.S. Dye-sensitized nanocrystalline solar cells based on composite polymer electrolytes containing fumed silica nanoparticles. Chem. Commun. 2004, 4, 1662-1663. [CrossRef] 
31. Gong, J.; Liang, J.; Sumathy, K. Review on dye-sensitized solar cells (DSSCs): Fundamental concepts and novel materials. Renew. Sustain. Energy Rev. 2012, 16, 5848-5860. [CrossRef]

32. Storck, J.L.; Dotter, M.; Brockhagen, B.; Grothe, T. Evaluation of Novel Glycerol/PEO Gel PolymerElectrolytes for Non-Toxic DyeSensitized Solar Cellswith Natural Dyes Regarding Long-Term Stabilityand Reproducibility. Crystals 2020, 10, 1158. [CrossRef]

33. Kuchariková, L.; Tillová, E.; Bokůvka, O. Recycling and Properties of Recycled Aluminium Alloys Used in the Transportation Industry. Transp. Probl. 2017, 11, 117-122. [CrossRef]

34. Daut, I.; Fitra, M.; Irwanto, M.; Gomesh, N.; Irwan, Y.M. TiO 2 Dye Sensitized Solar Cells Cathode Using Recycle Battery. J. Phys. Conf. Ser. 2013, 423, 012055. [CrossRef]

35. Gomesh, N.; Shafawi, M.; Irwanto, M.; Yusoff, M.I.; Fitra, M.; Mariun, N.; Nair, G. Performance Improvement of Dye Sensitized Solar Cell by Using Recycle Material for Counter Electrode. Appl. Mech. Mater. 2013, 446-447, 823-826. [CrossRef]

36. Hölscher, F.; Trümper, P.-R.; Junger, I.J.; Schwenzfeier-Hellkamp, E.; Ehrmann, A. Application methods for graphite as catalyzer in dye-sensitized solar cells. Optik 2019, 178, 1276-1279. [CrossRef]

37. Muchuweni, E.; Martincigh, B.S.; Nyamori, V.O. Recent advances in graphene-based materials for dye-sensitized solar cell fabrication. RSC Adv. 2020, 10, 44453-44469. [CrossRef]

38. Chen, C.C.; Chang, F.C.; Liao, C.Y.; Paul Wang, H. Copper Nanowires on Recycled Conducting Glass for DSSC Electrodes; TechConnect Briefs: Danville, CA, USA, 2012.

39. Ayaz, M.; Khan Kasi, J.; Khan Kasi, A.; Ali, M. Toward Eco Green Energy: Fabrication of DSSC from Recycled Phone Screen. Open Access J. Resist. Econ. Int. J. Resist. Econ. 2016, 4, 2345-4954.

40. Zhu, W.; Chai, W.; Chen, D.; Xi, H.; Chen, D.; Chang, J.; Zhang, J.; Zhang, C.; Hao, Y. Recycling of FTO/TiO 2 Substrates: Route toward Simultaneously High-Performance and Cost-Efficient Carbon-Based, All-Inorganic CsPbIBr2 Solar Cells. ACS Appl. Mater. Interfaces 2020, 12, 4549-4557. [CrossRef]

41. Bai, Y.; Mora-Sero, I.N.; De Angelis, F.; Bisquert, J.; Wang, P. Titanium Dioxide Nanomaterials for Photovoltaic Applications. Chem. Rev. 2014, 114, 10095-10130. [CrossRef]

42. Food Watch. Mineral Oil in Food-Results of the Foodwatch Test; Food Watch: Berlin, Germany, 2015; pp. 1-26.

43. Mariotti, N.; Bonomo, M.; Barolo, C. Emerging Photovoltaic Technologies and Eco-Design-Criticisms and Potential Improvements. In Reliability and Ecological Aspects of Photovoltaic Modules; Gok, A., Ed.; IntechOpen: London, UK, 2020.

44. Iftikhar, H.; Sonai, G.G.; Hashmi, S.G.; Nogueira, A.F.; Lund, P.D. Progress on Electrolytes Development in Dye-Sensitized Solar Cells. Materials 2019, 12, 1998. [CrossRef]

45. Hasan, M.M.; Islam, D.; Rashid, T.U. Biopolymer-Based Electrolytes for Dye-Sensitized Solar Cells: A Critical Review. Energy Fuels 2020, 34, 15634-15671. [CrossRef]

46. Singh, R.; Polu, A.R.; Bhattacharya, B.; Rhee, H.-W.; Varlikli, C.; Singh, P.K. Perspectives for solid biopolymer electrolytes in dye sensitized solar cell and battery application. Renew. Sustain. Energy Rev. 2016, 65, 1098-1117. [CrossRef]

47. Galliano, S.; Bella, F.; Bonomo, M.; Viscardi, G.; Gerbaldi, C.; Boschloo, G.; Barolo, C. Hydrogel Electrolytes Based on Xanthan Gum: Green Route Towards Stable Dye-Sensitized Solar Cells. Nanomaterials 2020, 10, 1585. [CrossRef]

48. Bella, F.; Gerbaldi, C.; Barolo, C.; Grätzel, M. Aqueous dye-sensitized solar cells. Chem. Soc. Rev. 2015, 44, 3431-3473. [CrossRef]

49. Dias, P.; Javimczik, S.; Benevit, M.; Veit, H. Recycling WEEE: Polymer characterization and pyrolysis study for waste of crystalline silicon photovoltaic modules. Waste Manag. 2017, 60, 716-722. [CrossRef]

50. Hellert, C.; Klemt, C.; Scheidt, U.; Junger, I.J.; Schwenzfeier-Hellkamp, E.; Ehrmann, A. Rehydrating dye sensitized solar cells. AIMS Energy 2017, 5, 397-403. [CrossRef]

51. Chen, R.-T.; Liao, C.-F. Evaluation and Optimization to Recycle Used $\mathrm{TiO}_{2}$ Photoelectrode for Dye-Sensitized Solar Cells. Int. J. Photoenergy 2014, 2014, 1-7. [CrossRef]

52. Chiang, Y.-F.; Chen, R.-T.; Shen, P.-S.; Chen, P.; Guo, T.-F. Extension lifetime for dye-sensitized solar cells through multiple dye adsorption/desorption process. J. Power Sources 2013, 225, 257-262. [CrossRef]

53. Wei, Q.S.; Aizat, M.F.; Diyanti, A.; Ishak, W.M.F.; Salleh, H.; Wong, K.N.S.W.S.; Adli, H.K. Kappaphycus alvarezii sp., Sargassum polycystum sp. and Manihot esculenta sp. as photo-sensitizers in dye-sensitized solar cells. AIP Conf. Proc. 2019. [CrossRef]

54. Mamun, A.; Trabelsi, M.; Klöcker, M.; Sabantina, L.; Großerhode, C.; Blachowicz, T.; Grötsch, G.; Cornelißen, C.; Streitenberger, A.; Ehrmann, A. Electrospun Nanofiber Mats with Embedded Non-Sintered $\mathrm{TiO}_{2}$ for Dye-Sensitized Solar Cells (DSSCs). Fibers 2019, 7, 60. [CrossRef]

55. Mozaffari, S.; Nateghi, M.R.; Zarandi, M.B. An overview of the Challenges in the commercialization of dye sensitized solar cells Renew. Sustain. Energy Rev. 2017, 71, 675-686. [CrossRef]

56. Parisi, M.L.; Maranghi, S.; Basosi, R. The evolution of the dye sensitized solar cells from Grätzel prototype to up-scaled solar applications: A life cycle assessment approach. Renew. Sustain. Energy Rev. 2014, 39, 124-138. [CrossRef]

57. Gonçalves, L.M.; Bermudez, V.D.Z.; Ribeiro, H.A.; Mendes, A. Dye-sensitized solar cells: A safe bet for the future. Energy Environ. Sci. 2008, 1, 655-667. [CrossRef]

58. Hagfeldt, A.; Boschloo, G.; Sun, L.; Kloo, L.; Pettersson, H. Dye-Sensitized Solar Cells. Chem. Rev. 2010, 110, 6595-6663. [CrossRef]

59. Hardin, B.E.; Snaith, H.J.; McGehee, M.D. The renaissance of dye-sensitized solar cells. Nat. Photonics 2012, 6, 162-169. [CrossRef]

60. Pramananda, V.; Fityay, T.A.H.; Misran, E. Anthocyanin as natural dye in DSSC fabrication: A review. IOP Conf. Ser.: Mater. Sci. Eng. 2021, 1122, 012104. [CrossRef] 
61. Kakiage, K.; Aoyama, Y.; Yano, T.; Oya, K.; Fujisawa, J.-I.; Hanaya, M. Highly-efficient dye-sensitized solar cells with collaborative sensitization by silyl-anchor and carboxy-anchor dyes. Chem. Commun. 2015, 51, 15894-15897. [CrossRef]

62. Yella, A.; Lee, H.-W.; Tsao, H.N.; Yi, C.; Chandiran, A.K.; Nazeeruddin, M.K.; Diau, E.W.-G.; Yeh, C.-Y.; Zakeeruddin, S.M.; Grätzel, M. Porphyrin-Sensitized Solar Cells with Cobalt (II/III)-Based Redox Electrolyte Exceed 12 Percent Efficiency. Science 2011, 334, 629-634. [CrossRef]

63. Wang, X.-F.; Zhan, C.-H.; Maoka, T.; Wada, Y.; Koyama, Y. Fabrication of dye-sensitized solar cells using chlorophylls c1 and c2 and their oxidized forms $\mathrm{c1}^{\prime}$ and $\mathrm{c2}^{\prime}$ from Undaria pinnatifida (Wakame). Chem. Phys. Lett. 2007, 447, 79-85. [CrossRef]

64. Zulkifli, A.M.; Said, N.I.A.M.; Aziz, S.B.; Dannoun, E.M.A.; Hisham, S.; Shah, S.; Abu Bakar, A.; Zainal, Z.H.; Tajuddin, H.A.; Hadi, J.M.; et al. Characteristics of Dye-Sensitized Solar Cell Assembled from Modified Chitosan-Based Gel Polymer Electrolytes Incorporated with Potassium Iodide. Molecues 2020, 25, 4115. [CrossRef]

65. Magni, M.; Giannuzzi, R.; Colombo, A.; Cipolla, M.P.; Dragonetti, C.; Caramori, S.; Carli, S.; Grisorio, R.; Suranna, G.P.; Bignozzi, C.A.; et al. Tetracoordinated Bis-phenanthroline Copper-Complex Couple as Efficient Redox Mediators for Dye Solar Cells. Inorg. Chem. 2016, 55, 5245-5253. [CrossRef] [PubMed]

66. Bella, F.; Sacco, A.; Salvador, G.P.; Bianco, S.; Tresso, E.; Pirri, C.; Bongiovanni, R. First Pseudohalogen Polymer Electrolyte for Dye-Sensitized Solar Cells Promising for In Situ Photopolymerization. J. Phys. Chem. C 2013, 117, 20421-20430. [CrossRef]

67. Kokal, R.K.; Bhattacharya, S.; Cardoso, L.S.; Miranda, P.B.; Soma, V.R.; Chetti, P.; Melepurath, D.; Raavi, S.S.K. Low cost 'green' dye sensitized solar cells based on New Fuchsin dye with aqueous electrolyte and platinum-free counter electrodes. Sol. Energy 2019, 188, 913-923. [CrossRef]

68. Meng, K.; Thampi, K.R. Efficient Quasisolid Dye- and Quantum-Dot-Sensitized Solar Cells Using Thiolate/Disulfide Redox Couple and CoS Counter Electrode. ACS Appl. Mater. Interfaces 2014, 6, 20768-20775. [CrossRef] [PubMed]

69. Chen, J.; Li, K.; Luo, Y.; Guo, X.; Li, D.; Deng, M.; Huang, S.; Meng, Q. A flexible carbon counter electrode for dye-sensitized solar cells. Carbon 2009, 47, 2704-2708. [CrossRef]

70. Kavan, L.; Yum, J.H.; Grätzel, M. Optically Transparent Cathode for Dye-Sensitized Solar Cells Based on Graphene Nanoplatelets. ACS Nano 2010, 5, 165-172. [CrossRef]

71. Peri, R.; P, M.K.; B, M. Improved performance of dye-sensitized solar cells upon sintering of a PEDOT cathode at various temperatures. RSC Adv. 2020, 10, 4521-4528. [CrossRef]

72. Chen, M.; Zhao, G.; Shao, L.-L.; Yuan, Z.-Y.; Jing, Q.-S.; Huang, K.-J.; Huang, Z.-Y.; Zhao, X.-H.; Zou, G.-D. Controlled Synthesis of Nickel Encapsulated into Nitrogen-Doped Carbon Nanotubes with Covalent Bonded Interfaces: The Structural and Electronic Modulation Strategy for an Efficient Electrocatalyst in Dye-Sensitized Solar Cells. Chem. Mater. 2017, 29, 9680-9694. [CrossRef]

73. Fayad, R.; Shoker, T.A.; Ghaddar, T.H. High photo-currents with a zwitterionic thiocyanate-free dye in aqueous-based dye sensitized solar cells. Dalton Trans. 2016, 45, 5622-5628. [CrossRef] [PubMed]

74. de Wild-Scholten, M.J.; Veltkamp, A.C. Environmental Life Cycle Analysis of Large Area Dye Sensitized Solar Modules; Status and Outlook. In Proceedings of the 22nd European Photovoltaic Solar Energy Conference and Exhibition, Milan, Italy, 3 September 2007; pp. 3-7.

75. McDonald, N.; Pearce, J. Producer responsibility and recycling solar photovoltaic modules. Energy Policy 2010, 38, 7041-7047. [CrossRef]

76. Peng, J.; Lu, L.; Yang, H. Review on life cycle assessment of energy payback and greenhouse gas emission of solar photovoltaic systems. Renew. Sustain. Energy Rev. 2013, 19, 255-274. [CrossRef]

77. EUR-Lex-32012L0019-EN-EUR-Lex. Available online: https://eur-lex.europa.eu/legal-content/EN/TXT/?uri=celex\%3A320 12L0019 (accessed on 8 June 2021).

78. Schmidt-Bleek, F. Green Lies. Nothing for the Environment, Everything for Business-How Politics and Industry are Ruining the World; Ludwig Verlag: Munich, Germany, 2014.

79. Blanco, C.F.; Cucurachi, S.; Peijnenburg, W.J.G.M.; Beames, A.; Vijver, M.G. Are Technological Developments Improving the Environmental Sustainability of Photovoltaic Electricity? Energy Technol. 2020, 8, 1901064. [CrossRef]

80. Wortmann, M.; Layland, A.S.; Frese, N.; Kahmann, U.; Grothe, T.; Storck, J.L.; Blachowicz, T.; Grzybowski, J.; Hüsgen, B.; Ehrmann, A. On the reliability of highly magnified micrographs for structural analysis in materials science. Sci. Rep. 2020, 10, 1-8. [CrossRef]

81. Baker, M. 1,500 scientists lift the lid on reproducibility. Nat. Cell Biol. 2016, 533, 452-454. [CrossRef] [PubMed]

82. NBSP. Reproducibility and Replicability in Science; National Academies Press: Washington, DC, USA, 2019. [CrossRef] 